\title{
PENERAPAN MODEL PEMBELAJARAN COURSE REVIEW HORAY UNTUK MENINGKATKAN HASIL BELAJAR SISWA MATERI SISTEM KLASIFIKASI MAKHLUK HIDUP PADA KELAS X SMA NEGERI 14 AMBON
}

\author{
Christin Tulaseket $^{1}$, F. Leiwakabessy ${ }^{2}$, D. Rumahlatu ${ }^{2}$ \\ ${ }^{1}$ Alumni Program Studi Pendidikan Biologi \\ 'Dosen Program Studi Pendidikan Biologi \\ E-mail: fredyleiwakabessy@yahoo.com
}

\begin{abstract}
Background: This study aims to determine the effect of the application of the learning model of the horay course review to improve student learning outcomes of teaching material on the classification system of living things in class $X$ of SMA Negeri 14 Ambon.

Method: Samples from this study were students of class X1 with 23 students. This type of research is descriptive research to see student learning outcomes which consists of 3 factors, namely physical, cognitive and psychomotor. The instruments used in this study were test instruments in the form of initial tests and final tests.

Results: The results of this study show that there is a significant effect by using the learning review horay learning model on improving student learning outcomes during the implementation of the learning model of the course review horay.

Conclusion: Based on the results of the study it can be concluded that the use of the Course Review Horay learning model can improve the learning outcomes of class X1 students at SMA Negeri 14 Ambon. This can be seen from the results of the final test which is very satisfying from the results of the initial test. Presentation of student grades during the initial test is $13 \%$ and the final test score reaches $100 \%$.
\end{abstract}

Keywords: Course review horay learning model, learning outcomes.

\begin{abstract}
Abstrak
Latar Belakang: Penelitian ini bertujuan untuk mengetahui pengaruh penerapan model pembelajaran course review horay untuk meningkatkan hasil belajar siswa materi ajar sistem klasifikasi makhluk hidup pada kelas X SMA Negeri 14 Ambon.

Metode: Sampel dari penelitian ini adalah siswa kelas $X_{1}$ dengan jumlah siswa 23 orang. Jenis penelitian ini adalah penelitian deskritif untuk melihat hasil belajar siswa yang terdiri dari 3 faktor yaitu fektif, kognitif dan psikomotor. Instrumen yang digunakan dalam penelitian ini adalah instrument tes berupa tes awal dan tes akhir.

Hasil: Hasil penelitian ini menujukkan bahwa ada pengaruh yang signifikan dengan menggunakan model pembelajaran course review horay terhadap peningkatan hasil belajar siswa pada saat keterlaksanaan model pembelajaran course review horay.

Kesimpulan: Berdasarkan hasil penelitian maka dapat disimpulkan bahwa penggunaan model pembelajaran Course Review Horay dapat meningkatkan hasil belajar siswa kelas $X_{1}$ SMA Negeri 14 Ambon. Hal ini dapat dilihat dari hasil tes akhir yang sangat memuaskan dari pada hasil tes awal. Presentasi nilai siswa saat tes awal sebesar $13 \%$ dan nilai tes akhir mencapai $100 \%$.
\end{abstract}

Kata Kunci : Model pembelajaran course review horay, hasil belajar. 


\section{PENDAHULUAN}

Model pembelajaran Course Review Horay adalah model pembelajaran yang menyenangkan karena setiap siswa yang dapat menjawab benar diwajibkan berteriak "horee" atau yel-yel lainnya yang disukai. Model ini berusaha menguji pemahaman siswa dalam menjawab soal, dimana jawaban soal tersebut dituliskan pada kartu atau kotak yang telah dilengkapi nomor. Menurut Siswanto (2012), menjelaskan bahwa, model Pembelajaran Course ReviewHoray (CRH),merupakan model pembelajaran yang dapat menciptakan suasana kelas menjadi meriah dan menyenangkan karena setiap siswa yang dapat menjawab benar maka siswa tersebut diwajibkan berteriak 'hore!'atau yel-yel lainnya yang disukai". Sholeh Hamid (2013), model pembelajaran Course Review Horay (CRH) merupakan model yang menyenagkan karena siswa di ajak untuk bermain sambil belajar untuk menjawab berbagai macam pertanyaan yang di sampaikan secarah menarik dari guru.

Sanjaya Wina (2013), menyatakan bahwa belajaradalah suatu proses aktivitas mental seseorang dalam berinteraksi denganlingkungannya sehingga menghasilkan perubahan tingkah laku yangbersifat positif, baik perubahan dalam aspek pengetahuan, afektif, maupunpsikomotorik. Menurut Slamento (2003) belajar merupakan suatu proses yang dilakukan oleh seseorang untuk memperoleh suatu perubahan tingkah laku yang baru secara keseluruhan sebagai hasil dari interaksi dirinya dengan lingkungan dimana ia berada.Kegiatan dan usaha mencapai perubahan dan tingkah laku itu merupakan proses belajar sedangkan perubahan tingkah laku sendiri merupakan hasil belajar. Dengan demikian belajar akan menyangkut proses dan hasil belajar (Ridwan, 2009).

SMA Negeri 14 Ambon merupakan salah satu sekolah yang terbuka karena dapat menerima peneliti-peneliti untuk melakukan penelitian terutama pada penelitian pendidikan.Dengan menerima peneliti yang ingin meneliti di sekolah ini,menandakan bahwa sekolah ini sangat berantusias dalam mendukung perkembangan dan kemajuan di bidang pendidikan.Selain itu,sekolah ini juga ingin mendapatkan informasi-informasi terkait dengan dunia pendidikan yang bermanfaat bagi pengembanganmutu pendidikan dan pembelajaran pada sekolah ini.

Berdasarkan hasil observasi dan wawancara secarah langsung penelitibersama kepala sekolah dan guru mata pelajaran biologi SMA NEGERI 14 Ambon, ternyata terdapat kendala yang dihadapi oleh guru mata pelajaran biologi. Kendala yang dihadapi guru mata pelajaran biologi tersebut adalah kurangnya hasil belajar siswa dalam proses pembelajaran. Siswa hanya mencatat, dan hanya ada sebagian siswa yang mendengarkan, lebih banyak bermain daripada memperhatikan materi yang diterangkan oleh guru.Berdasarkan kendala-kendala yang dihadapi sering membuat guru merasa kesulitan dalam menerapkan pembelajaran dan siswa juga kurang bergairah atau kurang aktif dalam mengikuti proses pembelajaran. Selain itu peneliti juga menemukan bahwa dalam proses belajar mengajar,guru sering menggunakan diskusi yang biasa dilakukan sehingga membuat siswa cepat bosan dan kurang aktif dalampembelajaran, hal ini sangat berpengaruh pada hasil belajar siswa dengan standar ketuntasan KKM yaitu 73 . Hasil yang diterima guru mata pelajaran dengan jumlah ketuntasan siswa hanya mencapai $50 \%$ sehingga hasil belajar siswa menurun. Memperhatikan permasalahan di atas, maka dibutuhkan suatu metode/model pembelajaran yang baik untuk menyelesaikan masalah yang dihadapai siswa pada SMA NEGERI 14 Ambon.

\section{MATERI DAN METODE}

Jenis penelitian yang digunakan dalam penelitian ini adalah penelitian deskriptif. Penelitian ini dilaksanakan pada SMA Negeri 14 Ambon. Penelitian dilaksanakan pada tanggal 3 April - 3 Mei 2017. Subjek dari penelitian ini adalah siswa kelas $X_{1}$ dengan jumlah 23 orang pada SMA Negeri 14 Ambon. Variabel yang digunakan dalam penelitian ini adalah variabel bebas: penerapan model pembelajaran course review horay dan variabel terikat: hasil belajar siswa. 
Proses pembelajaran yang akan berlangsung pada kelas $X_{1}$ melalui prosedur atau tahapan-tahapan sebagai berikut:

a. Menyiapkan program pengajaran berupa Silabus dan RPP

b. Melaksanakan kegiatan belajar mengajar menggunakan model pembelajaran course review horay

c. Mengadakan tes akhir setelah materi diajarkan.

Teknik analisis data yang digunakan adalah analisis deskriptif melalui beberapa tahapan yang dapat dijelaskan sebagai berikut:

1. Untuk hasil tes formatif, skor pencapaian diperoleh dengan cara:

$$
\text { skor pencapaian }=\frac{\text { skor yang diperoleh }}{\text { skor maksimum }} \times 100
$$

2. Untuk aspek kognitif diperoleh dari lembar kerja siswa (LKS), dimana siswa dibagikan ke dalam kelompok kemudian LKS akan diberikan kepada siswa di dalam kelompok dan dikerjakan. Proses penilaian pada LKS menggunakan rumus:

$$
\text { skor pencapaian }=\frac{\text { skor yang diperoleh }}{\text { skor maksimum }} \times 100
$$

3. Untuk hasil observasi, skor pencapaian diperoleh dengan cara:

skor pencapaian $=\frac{\text { skor yang diperoleh }}{\text { skor } \text { maksimum }} \times 100$

Selanjutnya untuk nilai proses (NP) diperoleh dengan cara:

$N P=\frac{\text { pencapaian kognitif }+ \text { pencapaian af ektif }+ \text { pencapaian unjuk rasa }}{3} \times 100$

Data yang terkumpul dianalisa untuk memperoleh nilai akhir (NA). 1) Penilaian secara proses (P) KBM dalam hal ini didapatkan dari penilaian kognitif, afektif dan psikomotor; 2) Nilai tes formatif (F). Bobot penilaian dari keduanya adalah $P=6$ dan $F=4$. Nilai akhir ditentukan dengan rumus

$N A \frac{6 P+4 F}{10}$

Pada tingkat penguasaan minimum (batas ketuntasan) secara individual 72 . Sementara nilai $P$ diperoleh dari penjumlahan nilai kognitif, Afektif,
Psikomotor per tiga dari hasil tes akhir, jumlah skor perolehan dikali jumlah skor maksimum dikali $100 \%$ (Arikunto, 2010) dimana Na: Nilai akhir; P: Nilai proses yang diperoleh dari nilai kognitif, afektif dan psikomotor; F: Nilai formatif setelah proses pembelajaran.

\section{HASIL DAN PEMBAHASAN}

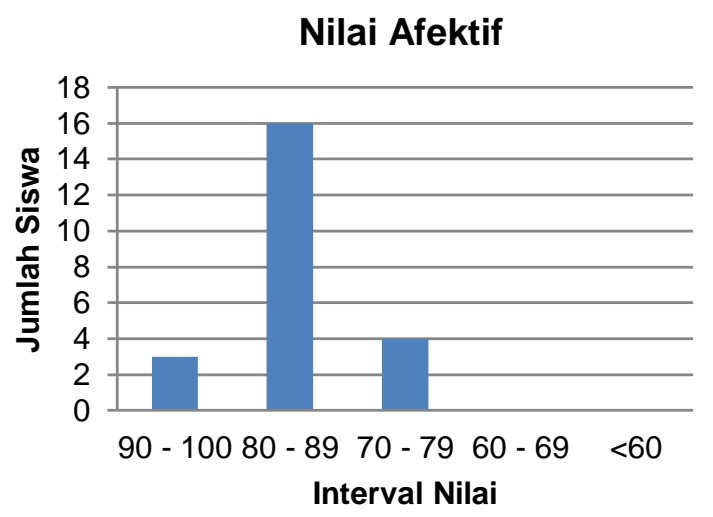

\section{Gambar 1. Grafik Penilaian Afektif}

Berdasarkan gambar 1 diatas. Dari 23 siswa kelas $X_{1}$ terdapat 3 orang (90-100) siswa yang berkategori sangat aktif, ada 16 orang (80-89) yang berkategori aktif, 4 orang (70-79) berkategori cukup aktif dan tidak ada siswa yang berkategori kurang aktif.

Pada pembelajaran di kelas $\mathrm{X}_{1}$, guru memberikan penjelasan tentanglangkahlangkah dalam melakukan pelajaran dengan menggunakan model pembelajaran Course Review Horay, sehingga siswa dapat memahami dengan baik agar dalam proses pembelajaran kelompok siswa dapat melakukannya dengan baik dan memberikan motivasi terhadap siswa serta membuat suasana lebih santai agar dapat mengurangi ketegangan. Hal tersebut membuat siswa tidak merasa takut untuk mengeluarkan pendapat dan saling berinteraksi dengan baik antara siswa dengan siswa ataupun siswa dengan guru. 


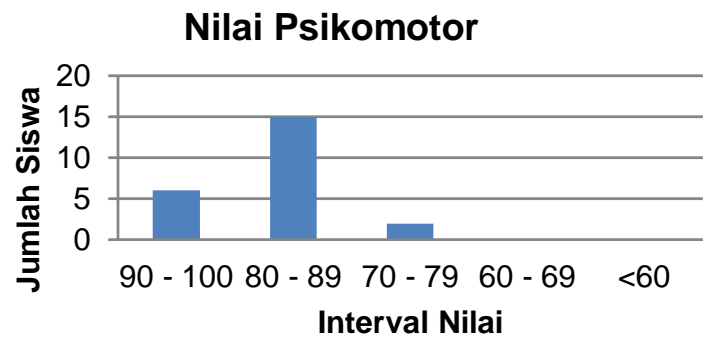

\section{Gambar 2. Grafik Penilaian Psikomotor.}

Pada gambar 2 dapat dilihat bahwa dalam proses belajar terdapat 6 orang (90100) siswa yang berkategori sangat aktif, ada 15 orang (80-89) yang berkategori aktif, 2 orang (70-79) berkategori cukup aktif dan tidak ada siswa yang berkategori kurang aktif. Pada pembelajaran di kelas $X_{1}$, guru membuat suasana lebih santai dan meriahdengan menggunakan model pembelajaran Course Review Horay yang dimana siswa menyanyikan yel-yel atau berteriak hore dalam proses pembelajaran berlangsung agar dapat mengurangi ketegangan dalam proses belajar mengajar.

$\mathrm{Hal}$ tersebut membuat siswa tidak merasa takut dan tegang dalam mengeluarkan pendapat dan saling berinteraksi dengan baik antara siswa dengan siswa ataupun siswa dengan guru. Selain itu siswa juga mampu untuk tampil dan percaya diri tanpa merasa takut.

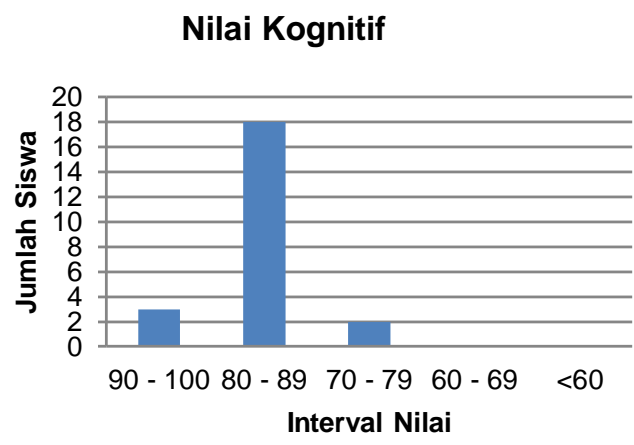

\section{Gambar 3. Grafik Penilaian LKS}

Pada Gambar 3 dapat dilihat bahwa pada saat proses belajar mengajar, siswa telah mampu untuk mendiskusikan dan mempresentasikan hasil kerja kelompok di dalam kelas dengan sangat baik.

Demikian karena, siswa telah mampu untuk menguasai apa yang mereka temukan saat melakukan pembelajaran terkait dengan klasifikasi makhluk hidup. Hal ini dapat membuat mereka bisa menjawab pertanyaan-pertanyaan yang diberikan. Aktivitas sebagian besar siswa dalam mengerjakan soal disajikan dalam bentuk soal tergolong baik dengan nilai rata-rata 83,48 . Hal tersebut karena siswa dapat

mengamati,memahami,mengelompokkan dan mencatat data hasil pengamatan kemudian menyimpulkannya dengan baik.

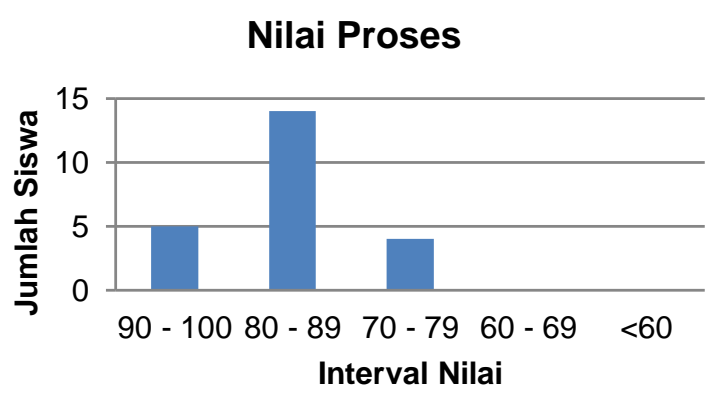

\section{Gambar 4. Grafik Perhitungan Nilai Proses}

Pada Gambar nilai 4 dapat dilihat bahwa rata-rata nilai proses belajar siswa selama melakukan pengamatan, mengumpulkan data, mendiskusikan hasil pengamatan di kelas dan menarik kesimpulan yaitu 83.29 Dari 23 siswa kelas $\mathrm{X}_{1}$ terdapat 5 orang (90-100) siswa yang berkategori sangat aktif, ada 14 orang (8089) yang berkategori aktif, 4 orang (70-79) berkategori cukup aktif dan tidak ada siswa yang berkategori kurang aktif. Pada pembelajaran di kelas $X_{1}$, guru memberikan membuat suasana lebih santai agar dapat mengurangi ketegangan, hal ini tersebut membuat siswa tidak merasa takut dan tegang dalam mengeluarkan pendapat dan saling berinteraksi dengan baik antara siswa dengan siswa ataupun siswa dengan guru. 


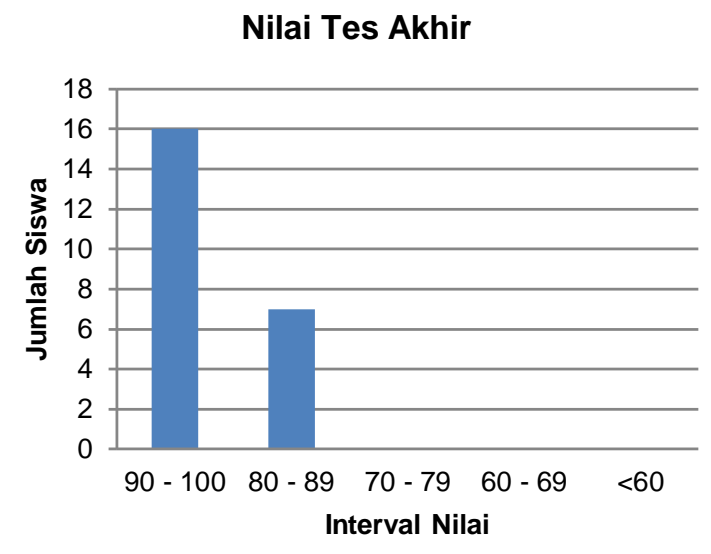

Gambar 5. Grafik Perhitungan Nilai Tes Akhir

Pada Gambar 5 grafik tes akhir dapat menggambarkan bahwa hasil tes akhir siswa kelas $\mathrm{X}_{1}$ setelah mendapat perlakuan khusus melalui penerapan model pembelajaran Course Review Horay pada materi klasifikasi makhluk hidup secara keseluruhan mencapai nilai rata-rata 90 atau berkategori baik. Nilai rata-rata tersebut dapat dikatakan memuaskan karena telah mencapai KKM 73. Dari 23 orang siswa, sebanyak 16 orang (90-100) berkualifikasi sangat baik, 7 orang (70-79) berkualifikasi baik. Tidak ada orang yang berkualifikasi cukup dan tidak baik. Penelitian ini juga didukung oleh penelitian sebelumnya yaitu penelitia Nugroho (2011).

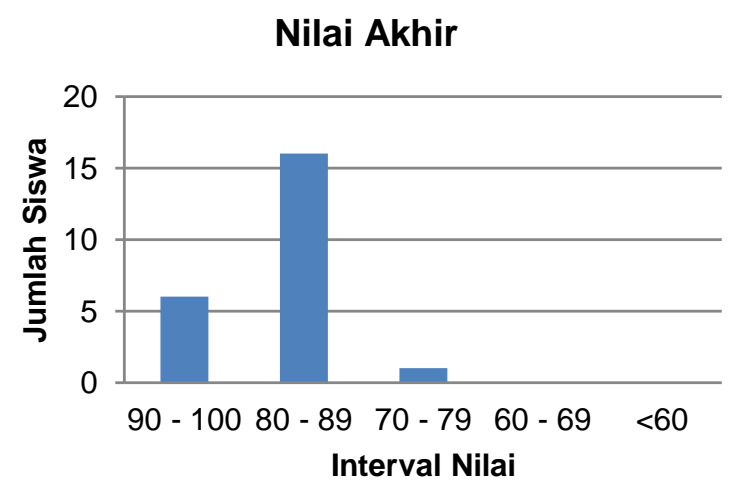

\section{Gambar 6.Grafik Perhitungan Nilai Akhir}

Pada Gambar 6. dapat dilihat bahwa hasil perhitungan nilai akhir siswa kelas $X_{1}$ setelah mendapat perlakuan khusus melalui penerapan model pembelajaran Course Review Horaypada materiklasifikasi makhluk hidup secara keseluruhan mencapai nilai rata-rata 90,00 atau berkategori baik. Nilai rata-rata tersebut dapat dikatakan memuaskan karena telah mencapai KKM 73. Dari 23 orang siswa, sebanyak 6 orang (90-100) berkualifikasi sangat baik, 16 orang berkualifikasi baik, 1 orang (70-79) berkualifikasi cukup. Tidak ada orang yag berkualifikasi kurang dan tidak baik. Berdasarkan grafik tersebut, nilai antara 80-89 adalah nilai yang paling banyak diperoleh siswa dan nilai antara 90100 adalah nilai yang paling sedikit diperoleh oleh siswa.

Berdasarkan uraian hasil tersebut dapat dinyatakan bahwa peningkatan kemampuan penguasaan konsep siswa kelas $\mathrm{X}_{1}$ pada materi klasifikasi mahkluk hidup merupakan suatu proses yang perlu dibanggakan karena dalam proses pembelajaran tingkat kemampuan siswa dalam mengikuti pembelajaran sangat berkembang dan memuaskan karena siswa sangat aktif dan bersemangat dalam proses belajar mengajar tidak ada ketenggangan dalam kelas karena menggunakan model pembelajaran yang menarik dan juga menghibur sehingga siswa merasa percaya diri dan tak ada rasah takut dalam proses pembelajaran . Dapat di lihat sebelum diberlakukan tindakan pembelajaran dengan menerapkan model pembelajaran Course Review Horay, kemampuan penguasaan konsep siswa pada materi klasifikasi mahkluk hidup masih rendah dan belum memenuhi target yang telah ditetapkan yaitu sebesar 73.Setelah diterapkan pembelajaran klasifikasi mahkluk hidup melalui penerapan model pembelajaran Course Review Horaymakaada peningkatan hasil belajar. Penelitian ini juga didukung oleh penelitian sebelumnya yaitu penelitian milik Dimyanti dan Mudjiono (2013).

\section{KESIMPULAN}

Berdasarkan hasil penelitian maka dapat disimpulkan bahwa penggunaan model pembelajaran Course Review Horay dapat meningkatkan hasil belajar siswa kelas $X_{1}$ SMA Negeri 14 Ambon. Hal ini dapat dilihat dari hasil tes akhir yang sangat memuaskan dari pada hasil tes awal. Presentasi nilai siswa saat tes awal adalah $13 \%$ dan nilai tes akhir $100 \%$ sangat 
memuaskan yaitu karena telah melewati KKM yaitu 73 .

\section{DAFTAR PUSTAKA}

Arikunto, Suharsimi, 2006. Prosedur Penelitian Suatu Pendekatan Praktek. Jakarta :Rineka Cipta.

Dimyati dan Mudjiono, 2010. Belajar dan Pembelajaran.Rineka Cipta: Jakarta.

Hamid, Sholeh, 2013. Metode Edutainment Menjadi Siswa Kreatif dan Nyaman di Kelas. Yogyakarta: DIVA Press.

Nugroho, 2011. Penerapan model pembelajaran Course Review Horay untukMeningkatkan pembelajaran IPA siswa kelas Vc SDN Bandung Grejosari 1 Kota Malang oleh Davis Dwi Cahyo Nugroho. Universitas Muhamadiyah Malang.

Ridwan, 2009. Pengertian Belajar.

Sanjaya, Wina, 2013. Strategi Pembelajaran Berorientasi Standar Proses Pendidikan. Bandung: Kencana.

Slamento, 2003. Belajar dan Faktor-Faktor yang Mempengaruhinya. Jakarta: Rineka Cipta.

Siswanto,F. 2012. Model Pembelajaran Course Review Horay ( $\mathrm{CRH}$ ) [online] http://eduadventure.com oktober 2014. Diakses $22 \quad$ Juli 2017. 